\title{
PENGARUH BIMBINGAN SOSIAL TERHADAP KEMANDIRIAN
}

\author{
Ani Endriani ${ }^{1}$, Ivan Aswansyah ${ }^{2}$, Ade Sanjaya ${ }^{3}$ \\ Program Studi Bimbingan dan Konseling, FIPP UNDIKMA \\ Email:aniendriani@ikipmataram.ac.id
}

\begin{abstract}
Abstrak: Bimbingansosial adalah seperangkat usaha bantuan kepada peserta didik agar dapat menghadapi sendiri masalah-masalah sosial yang dialaminya, mengadakan penyesuaian sosial, memilih kelompok sosial, memilih jenis-jenis kegiatan sosial dan kegiatan rekreatif yang bernilai guna, serta berdaya upaya sendiri dalam memecahkan masalah-masalah sosial yang dialaminya. Kemandirianadalah kemampuan untuk mengelola semua milik kita, tahu bagaimana mengelola waktu, berjalan dan berfikir secara mandiri, disertai kemampuan untuk mengambil resiko dan memecahkan masalah yang adadalamdirikita. Rumusan masalah dalampenelitianiniadalahapakahadapengaruhbimbingansosial terhadapkemandirianpadasiswakelas VII SMPN 1 Jonggat Lombok Tengah.Tujuandalampenelitianini adalahinginmengetahuipengaruhbimbingansosial terhadapkemandirianpadasiswakelas VII SMPN 1 Jonggat Lombok.Adapun jenis eksperimen yang digunakan dalam penelitian ini adalah Pre-experimental Design (nondesign) atau eksperimen tidak murni, dan salah satu bentuk eksperimennya adalah One-Group Pretest-Posttest Design. Populasi penelitian adalah seluruh siswa kelas VII SMPN 1 Jonggat Lombok Tengah sejumlah 150 orang siswa, sampel yang digunakan adalah 30 orang siswa yang diambil dari $20 \%$ dari jumlah populasi, hasil wawancara dan diperkuat dari hasil angket. Dalam penelitian ini, metode pengumpulan data yang digunakan adalah metode angket sebagai metode pokok. Teknik analisis data menggunakan analisis statistik dengan rumus t-test. Hasil yang diperoleh dalam penelitian ini t hitung lebih besar dari t tabel $(12,568>2,045)$ dengan demikian penelitian ini signifikan sehingga kesimpulan yang diperoleh dalam penelitian ini adalah Ada Pengaruh Bimbingan Sosial Terhadap Kemandirian Pada Siswa Kelas VII SMPN1 Jonggat Lombok Tengah.
\end{abstract}

\section{Kata Kunci :BimbinganSosial, Kemandirian}

\section{PENDAHULUAN}

Bimbingan merupakan

bimbingan yang membantu siswa mengenal dan berhubungan dengan lingkungan sosial yang dilandasi budi pekerti luhur, tanggung jawab, kemasyarakatan dan kenegaraan. Dengan menerapkan bimbingan sosial, guru dapat membantu siswa dalam meningkatkan proses perkembangan peserta didik yang tidak lepas dari pengaruh lingkungan, terutama lingkungan keluarga yang didalamnya ada orang tua sebagai pendidik, maka yang dimaksud dengan bimbingan sosial adalah:suatu bimbingan membantu siswa mengenal dan berhubungan dengan lingkungan sosial yang dilandasi budi pekerti luhur, tanggung jawab kemasyarakatan dan kenegaraan (Sukardi, 2007: 55).Sedangkan ahli lain mengatakan bahwa bimbingan sosial merupakan suatu bimbingan atau bantuan dalam menghadapi dan memecahkan masalah-masalah sosial seperti pergaulan, penyelesaian masalah konflik, penyesuain diri dan sebagainya. Bimbingan sosial juga bermakna suatu bimbingan atau bantuan dari pembimbing kepada individu agar dapat mewujudkan pribadi yang mampu bersosialisasi dan menyesuaikan diri dengan lingkungannya secara baik. (Tohirin, 2013: 125)

Berdasarkan pendapat tersebut diatas peneliti dapat menyimpulkan bahwa yang dimaksud dengan bimbingan sosial adalah: seperangkat usaha bantuan kepada peserta didik agar dapat menghadapi sendiri masalahmasalah sosial yang dialaminya, membantu peserta didik berdaya upaya sendiri dalam memecahkan masalah-masalah sosial yang dialaminya. Dengan diterapkannya bimbingan sosial secara rutin disekolahakan membantu siswa dalam meningkatkan pemahaman diri dan pembentukan kemandirian pada siswa.

Yuliani(2007:66)mengatakan bahwa kemandirian adalah suatu upaya yang dilakukan dan dimaksudkan untuk melatih anak dalam memecahkan masalahnya.Sedangkan menurut Fatimah (2010: 149) mengatakan bahwa kemandirian meliputi perilaku mampu berinisiatif, mampu 
mengatasi masalah, mempunyai rasa percaya diri dan dapat melakukan sesuatu sendiri tanpa bantuan orang lain, serta bertanggung jawab terhadapapa yang dilakukan.Sedangkan menurut Parker (2006: 66)mengatakan bahwa kemandirian adalah: kemampuan untuk mengelola semua milik kita,tahu bagaimana mengelola waktu anda, berjalan dan berfikir secara mandiri, disertai kemampuan untuk mengambil resiko danmemecahkan masalah

\section{KAJIAN LITERATUR}

\section{Konsep Bimbingan Sosial}

Menurut Tohirin (2013:125)

"bimbingan sosial merupakan suatu bimbingan atau bantuan dalam menghadapi dan memecahkan masalah-masalah sosial seperti pergaulan, penyelesaian masalah konflik, penyesuain diri dan sebagainya. Bimbingan sosial juga bermakna suatu bimbingan atau bantuan dari pembimbing kepada individu agar dapat mewujudkan pribadi yang mampu bersosialisasi dan menyesuaikan diri dengan lingkungannya secara baik". Sedangkan menurut Sukardi (2007 : 55) bahwa bimbingan sosial merupakan suatu bimbingan membantu siswa mengenal dan berhubungan dengan lingkungan sosialnya yang dilandasinya budi pekerti luhur, tanggung jawab kemasyarakatan dan kenegaraan.

Dari beberapa pendapat diatas peneliti dapat menyimpulkan bahwa yang dimaksud dengan bimbingan sosial adalah: bimbingan yang bertujuan untuk membantu proses pengembangan potensi diri melalui pola-pola sosial yang dilakukannya seharihari di lingkungan sekolah, keluarga dan masyarakat. Pola-pola sosial yang dimaksudkan adalah pola-pola dimana individu tersebut dapat melakukan penyesuaian diri dengan lingkungannya.

\section{Tujuan Bimbingan sosial}

Menurut Tohirin(2013: 125) tujuan utama pelayanan bimbingan sosial adalah: agar individu yang dibimbing mampu melakukan interaksi sosial secara baik dengan lingkungannya. Bimbingan sosial juga bertujuan membantu individu dalam memecahkan dan mengatasi kesuitankesulitan dalam sosial, sehingga individu dapat menyesuaikan diri secara baik dan wajar dalam lingkungan sosialnya.

Dalam konteks manusia sebagai makhluk sosial dan sebagai makhluk ciptaan Allah S.W.T. Dahlan (1989) menyatakan bahwa tujuan bmbingan sosial adalah: agar induvidu mampu mengembangkan diri secara optimal sebagai makhluk sosial dan makhluk ciptaan Allah S.W.T.

Menurut Sukardi (2004: 29), mengungkapkan tujuan dari bimbingan sosial adalah untuk membantu siswa agar: (a) Memiliki kesadaran diri, yaitu menggambarkan penampilan dan mengenal kekhususan yang ada pada dirinya (b) Dapat mengembangkan sikap positif, seperti menggambarkan orang-orang yang mereka senangi, (c) Membuat pilihan secara sehat (d) Mampu menghargai orang lain, (e) Memiliki rasa tanggung jawab, (f) Mengembangkan keterampilan hubungan antar pribadi, (g) Dapat menyelesaikan konflik (g) dan dapat membuat keputusan secara efektif.

Dari pendapat para ahli diatas mengenai tujuan dari bimbingan sosial dapat disimpulkan bahwa tujuan bimbingan sosial adalah: membantu individu atau sekumpulan individu (siswa) untuk mampu menerima dan memahami dirinya sendiri serta lingkungan sekitarnya sehingga individu atau sekumpulan individu dapat menyelesaikan permasalahan yang muncul dari dalam diri maupun lingkungan sekitar. Tujuan ini kiranya relevan dengan karakteristik pada diri siswa yang masuk pada usia remaja. Pada usia remaja, siswa mengalami banyak konflik, baik yang menyangkut masalah pribadi maupun sosial, oleh karena itu usia remaja dituntut agar mampu menyesuaikan diri.

\section{Bentuk-bentuk bimbingan sosial}


Menurut Tohirin (2013: 124 ) ada beberapa macam bentuk-bentuk layanan bimbingan sosial yang bisa diberikan kepada siswa di sekolah atau madrasah yaitu: (1) Layanan informasi. Layanan informasi yaitu informasi tentang keadaan masyarakat dewasa ini, informasi tentang ciri-ciri masyarakat maju atau modern, makna ilmu pengetahuan, pentingnya IPTEK bagi kehidupan manusia dan lain-lain, dan informasi tentang cara bergaul. Informasi tentang cara-cara berkomunikasi penting diberikan kepada setiap individu.Sebagai mahluk sosial, individu perlu berhubungan dengan orang. Dengan perkataan lain, individu memerlukan orang lain dalam kehidupannya. Individu dituntut untuk mampu beradap tasi (menyesuaikan diri)dengan lingkungannya). (2). Layanan orientasi yaitu layanan untuk bidang perkembangan hubungan sosial yang meliputi suasana, lembaga, dan objek-objek pengembangan sosial seperti berbagai suasana hubungan sosial antarindividu dalam keluarga, organisasi atau lembaga tertentu dalam acara sosial tertentu.

\section{Materi Bimbingan Sosial}

Menurut Sukardi (2008: 54), mengatakan bahwa materi bidang bimbingan sosial dapat dirinci menjadi pokok-pokok sebagai berikut: (a) Pemantapan sikap dan kebiasaan serta pengembangan wawasan dalam beriman dan bertakwa terhadap Tuhan Yang Maha Esa, (b) Pemantapan pemahaman tentang kekuatan diri dan pengembangannya untuk kegiatan-kegiatan yang kreatif liar, dan produktif, baik dalam kehidupan sehari-hari maupun untuk peranannya dimasa depan, (c) Pemantapan pemahaman tentang kelemahan diri dan usaha penanggulangannya, (d) Pemantapan kemampuan mengambil keputusan,(e) Pemantapan kemampuan mengarahkan diri sesuai dengan keputusan yang telah diambilnya, (f) Pemantapan dalam perencanaan dan penyelenggaraan hidup sehat, baik secara rohaniah maupun jasmaniah,(g) Pemantapan kemampuan berkomunikasi, baik melalui ragam lisan maupun tulisan secara efektif, (h) Pemantapan kemampuan menerima dan menyampaikan isi pendapat serta berargumentasi secara dinamis, kreatif dan produktif, (i) Pemantapan kemampuan bertingkah laku dan berhubungan sosial, baik di rumah, di sekolah maupun di masyarakat luas dengan menjunjung tinggi tata krama, sopan santun, serta nilai-nilai agama, adat, hukum, ilmu dan kebiasaan yang berlaku, (j) Pemantapan hubungan yang dinamis, harmonis dan produktif dengan teman sebaya, baik di sekolah yang sama, di sekolah yang lain, di luar sekolah, maupun di masyarakat pada umumnya, (k) Pemantapan pemahaman kondisi dan peraturan sekolah serta upaya pelaksanaannya secara dinamis dan bertanggung jawab.

\section{Konsep Kemandirian}

Menurut Chaplin (dalam Desmita (2009 : 185) kemandirian adalah kebebasan individu untuk memilih, untuk menjadi kesatuan yang bisamemerintah, menguasai dan menentukan dirinya sendiri. Sedangkan Sumahamijaya (2003: 30) menyatakan bahwa kemandirian adalah hal atau keadaan dapat berdiri sendiri tanpa tergantung pada orang lain. Sinonim dari kata mandiri adalah berdikari yang artinya berdiri diatas kaki sendiri, tidak bergantung pada bantuan orang lain.

Sedangkan menurut Ali dan Asrori (2010: 114) mengatakan bahwa kemandirian merupakan suatu kekuatan internal individu yang diperoleh melalui proses individuasi.Proses individuasi itu adalah proses realisasi kedirian dan proses menuju kesempurnaan. Diri adalah inti dari kepribadian dan merupakan titik pusat yang menyelaraskan dan mengoordinasikan seluruh aspek kepribadian. Kemandirian yang terintegrasi dan sehat dapat dicapai melalui proses peragaman, perkembangan, dan ekspresi system kepribadian sampai pada tingkatan yang tertinggi”, 
Berdasarkan pendapat ahli di atas dapat peneliti simpulkan bahwa, kemandirian adalah suatu kekuatan internal individu yang diperoleh melalui proses individualis atau keadaan dapat berdiri sendiri tanpa tergantung pada orang lain.

\section{Aspek- Aspek Kemandirian}

Havighurts (dalam Fatimah, 2010:143) menambahkan ada 4 (empat) aspek-aspek kemandirian yaitu: 1) Emosi,aspek ini ditunjukkan dengan kemampuan mengontrol emosi dan tidak tergantungnya kebutuhan emosi dari orang tua, 2) Ekonomi,aspek ini ditunjukkan dengan kemampuan mengatur ekonomi dan tidak tergantungnya kebutuhan ekonomi pada orang tua, 3) Intelektual, aspek ini ditunjukkan dengan kemampuan untuk mengatasi berbagai masalah yang dihadapidan 4) Sosial, aspek ini ditunjukkan dengan kemampuan untuk mengadakan interaksi dengan orang lain dan tidak tergantung atau menunggu aksi dari orang lain.

\section{Jenis-Jenis Kemandiran}

Jenis-jenis kemandirian (dalam Yamin \& Sanan, 2013: 80) yaitu:1) Kemandirian sosial dan emosi.Kemandirian emosional yakni aspek kemandirian yang menyatakan perubahan kedekatan hubungan emosional antar individu, seperti hubungan emosional peserta didik dengan guru atau dengan orang tuanya.(2) Kemandirian fisik dan fungsi tubuh, kemandirian secara fisik dan fungsi tubuh maksudnya adalah kemandirian dalam hal memenuhi kebutuhan. Misalnya, anak butuh makan, maka secara mandiri anak harus bisa makan sendiri, dll.(3) Kemandirian intelektual, bagaimana anak dapat mandiri belajar dan memperoleh pengetahuan. Kemandirian intelektual pada anak dapat dilihat dari bagaimana anak dapat menyelesaikan tugas sekolahnya sendiridan anak diberikan kesempatan untuk mengerjakan semua tanggungjawab, tetap dengan pengawasan orang tua.(4)
Menggunakan lingkungan untuk belajar. Anak menggunakan lingkungan untuk belajar serta dapat membantu orang lain untuk belajar mandiri.Anak dapat mandiri jika ia diberikan ruang untuk mengeksplor apa yang disenanginya tanpa dibantu atau ikut campur oleh orang dewasa atau lainnya. Anak akan menjadi mandiri begitu ia nyaman dengan lingkungannya.(5) Membuat keputusan dan pilihan,anak yang mandiri dapat membuat keputusan dan pilihan. Suatu kemampuan untuk membuat keputusan-keputusan tanpa tergantung pada orang lain dan melakukannya secara bertanggung jawab merupakan kemandirian tingkah laku" (Fatimah, 2010: 187).

\section{Proses Perkembangan Kemandirian}

Kemandirian, seperti halnya psikologis lain, dapat berkembang dengan baik jika diberikan kesempatan untuk berkembang melalui latihan yang dilakukan secara terus menerus dan dilakukan sejak dini. Latihan tersebut dapat berupa permberian tugas-tugas tanpa bantuan,dan tentu saja tugas-tugas tersebut disesuaikan dengan usia dan kemampuan anak"(Fatimah, 2010: 144)

Dengan asumsi bahwa kemandirian sebagai aspek psikologis berkembang tidak dalam kevakuman atau diturunkan oleh orang tuanya, maka intervensi positif melalui ikhtiar pengembangan atau pendidikan sangat diperlukan bagi kelancaran perkembangan kemandirian remaja, adapun intervensi dapat dilakukan sebagai ikhtiar pengembangan kemandirian remaja, antara lain sebagai berikut" (Ali \& Asrori, 2012: 119)yakni ;1). Penciptaan partisipasi dan keterlibatan remaja dalam keluarga, saling menghargai antar anggota keluarga, 2).Penciptaan keterbukaan, toleransi terhadap perbedaan pendapat, 3).Penciptaan kebebesan untuk mnehekplorasi lingkungan, 4).Penerimaan positif tanpa syarat, menerima kekurangan dan kelebihan pada remaja, 5).Empati terhadap remaja, mampu mengahyati 
perasaan remaja dan 6).Penciptaan hubungan yang hangat dengan remaja.

\section{Kemandirian Sebagai Kebutuhan Psikologis Remaja}

Memperoleh kebebasan (mandiri) merupakan suatu tugas bagi remaja.Dengan kamandirian tersebut, remaja harus belajar dan berlatih dalam membuat rencana, memilih alternatif, membuat keputusan, bertindak sesuai dengan keputusannya sendiri serta bertanggung jawab atas segala sesuatu yang dilakukannya.Dengan demikian, iaakan berangsur-angsur melepaskan diri dari ketergantungan kepada orang tua atau orang dewasa. Pendapat ini diperkuat oleh para ahli perkembangan yang menyatakan "berbeda dengan kemandirian pada masa anak-anak yang lebih bersifat motorik, seperti berusaha makan sendiri, pada remaja kemandirian tersebut lebih bersifat psikologis, seperti membuat keputusan sendiri dana kebebasan berprilaku sesuai dengan keinginannnya" (Fatimah, 2010: 144)

Dalam pencarian identitas diri, remaja cenderung untuk melepaskan diri sendiri sedikit demi sedikit dari ikatan psikis orangtuanya. Hal ini dikemukakan Erikson (dalam Fatimah, 2010: 145) yang menanamkan proses tersebut sebagai "proses mencari identitas ego", atau pencarian diri sendiri.

Kemandirian seorang remaja diperkuat melalui proses sosialisasi yang terjadi antar remaja dan teman sebaya. Hurlock (dalam Fatimah, 2010: 145) mengatakan bahwa melalui hubungan dengan teman sebaya, remaja belajar berfikir secara mandiri, mengambil keputusan sendiri, menerima (bahkan dapat juga menolak) pandangan dan nilai yang berasal dari keluarga dan mempelajari pola perilaku yang diterima di dalam kelompoknya.

Dalam mencapai keinginannya untuk mandiri, sering remaja mengalami hambatanhambatan yang disebabkan masih adanya kebutuhan untuk tetap bergantung kepada orang lain. Dalam contoh yang disebutkan diatas, remaja mengalami dilema yang sangat besar antara mengikuti kehendak orangtua atau mengikuti keinginannya. Situasi ini sering dikenal sebagai keadaan yang ambivalensi dan akan menimbulkan konflik dalam diri remaja. Konflik ini ini akan mempengaruhi remaja dalam usahanya untuk mandiri, sehingga sering menimbulkan hambatan dalam penyesuaian diri terhadap lingkungan sekitarnya. Bahkan, dalam beberapa kasus tidak jarang remaja menjadi frustasi dan memendam kemarahan yang mendalam kepada orangtua dan lingkungan sekitarnya, dan hal itu yang dapat menghambat tercapainya kedewasaan dan kematangan kehidupan psikologisnya. Oleh karena itu pemahaman orang tua terhadap kebutuhan psikologis remaja untuk dapat mandiri sangat diperlukan dalam upaya mendapatkan titik tengah penyelesaian konflik-konflik yang dihadapi remaja"(Fatimah, 2010: 146).

\section{Tingkatan dan karateristik kemandirian}

Lovinger (dalam Desmita, 2014 :

2012: 187-188) mengemukakan tingkatan kemandirian beserta ciri-cirinya sebagai berikut:1. Tingkatan pertama, adalah tingkakan impulsife dan melindungi diri.Ciriciri tingkatan ini adalah: a).Peduli terhadap control dan keuntungan yang diperoleh dari interaksinya dengan orang lain dan b). Cenderung menyalahkan dan mencela orang lain serta lingkungannya.2.Tingkatan kedua, adalah tingkat konformistik.Ciri-ciri tingkatan ini adalah: a).Peduli terhadap penampilan diri dan penerimaan social, b). Takut tidak diterima kelompok, dan c).Tidak sensitive terhadap keindividuan.3.Tingkatan ketiga, adalah tingkat sadar diri.Ciri-ciri tingkatan ini adalah:a).Mampu berfikir alternatife dan b). Melihat harapan dan berbagai kemungkinan dalam situasi.4.Tingkatan keempat, adalah tingkat seksama. Ciri-ciri tingkatan ini adalah : a). Bertindak atas dasar-dasar nilai internal dan b). Mampu melihat diri sebagai pembuat pilihan dan pelaku tindakan.5.Tingkatan 
kelima, adalah tingkat individualitas.Ciri-ciri tingakatan ini adalah:a).Peningkatan kesadaran individualitas dan b).Menjadi lebih toleran terhadap diri sendiri dan orang lain.6).Tingkatan keenam, adalah tingkat mandiri. Ciri-ciri tingkatan ini adalah:b). Memiliki pandangan hidup sebagai suatu keseluruhandan b). Cenderung bersikap realistik dan objektif terhadap diri sendiri maupun orang lain.

Berdasarkan pendapat diatas dapat disimpulkan bahwa karateristik kemandirian mencakup perlindungan yang dilakukan terhadap diri sendiri, seperti pengontrolan diri, adanya sikap sosial yang baik, mampu berfikir realistis, berbuat sesuai dengan aturan yang berlaku di dalam lingkungan masyarakat, dan tentunya memiliki pandangan hidup yang jelas serta kemampuan menyelesaikan segala permasalahan.

\section{Ciri-Ciri Sikap Mandiri}

Menurut Hasan Basri (2000 :56) berpendapat bahwa individu yang mandiri mempunyai cirri-ciri sebagai berikut: a. Menghasilkan inisiatif dan berusahan untuk mengejar prestasi b. Secara relative jarang mencari pertolongan pada orang lain. c. Menunjukan rasa percaya diri. d. Mempunyai rasa ingin menonjol.

Ciri khas kemandirian pada anak diantaranya mereka memiliki kecenderungan dan kemampuan dalam memecahkan masalah dari pada berkutat dalam kekhawatiran bila terlibat masalah.Anak yang mandiri tidak takut dalam mengambil resiko karena sudah mempertimbangkan hasil sebelum berbuat.Anak yang mandiri percaya terhadap penilaian sendiri, sehingga tidak sedikitsedikit bertanya atau meminta bantuan.Anak yang mandiri memiliki kontrol yang lebih baik terhadap kehidupannya. Covey (1997 :38-39)menegaskan bahwa kemandirian memiliki ciri-ciri, diantarnya: (1) secara fisik mampu bekerja sendiri, (2) secara mental dapat berpikir sendiri serta mengambil keputusan, (3) secara kreatif mampu mengekspresikan gagasannya dengan cara yang mudah dipahami, dan (4) secara emosional kegiatan yang dilakukannya dipertanggungjawabkan sendiri.

\section{METODE PENELITIAN}

Adapun jenis jenis eksperimen yang digunakan dalam penelitian ini adalah Preexperimental Design (nondesign) atau eksperimen tidak murni, karena desain ini belum merupakan desain eksperimen sungguh-sungguh, masih terdapat variabel luar yang ikut berpengaruh terhadap terbentuknya variabel (Sugiyono, 2010: 109). Desain yang digunakan adalah OneGroup Pretest-Posttest Design.Pada desain ini terdapat pretest, sebelum diberi perlakuan.Dengan demikian hasil perlakuan dapat diketahui lebih akurat,karena dapat membandingkan keadaan sebelum diberi perlakuan. Desain ini dapat digambarkan seperti berikut:

Desain ini dapat digambarkan seperti berikut:

$$
\mathrm{O}_{1} \quad \mathrm{XO}_{2}
$$

Gambar 1. One- Group Pretest-Postest Design(Sugiyono, 2013: 111)

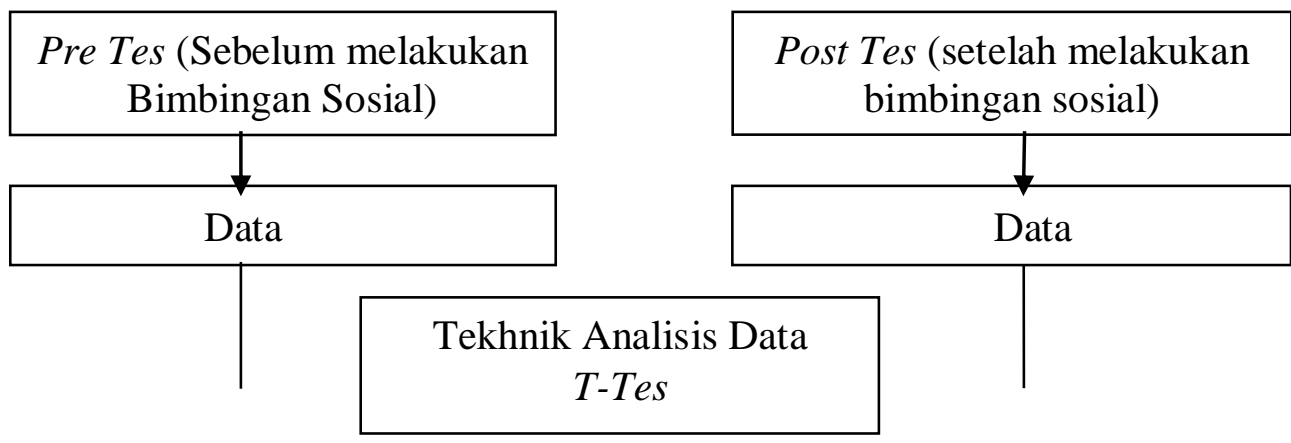




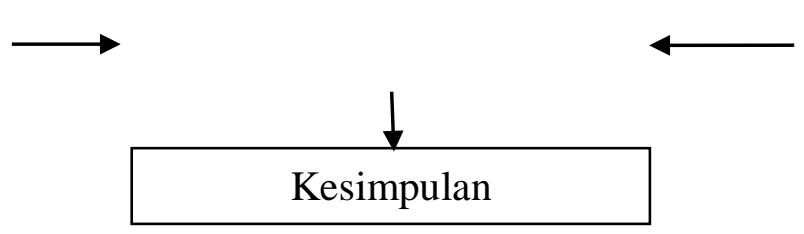

Gambar 2. Rancangan Penelitian

Populasi dari penelitian ini adalah seluruh siswa kelas VII SMPN 1 Jonggat Lombok Tengah yang berjumlah 150 orang siswa.Sampel yang akan digunakan adalah sesuai dengan teknik penentuan sampel. Dimana teknik sampling yang digunakan oleh peneliti ini jika peneliti mempunyai pertimbangan-pertimbangan tertentu di dalam pengambilan sampelnya. Menurut pendapat Arikunto(2002:112) jika jumlah populasi kurang dari 100 orang, maka lebih baik diambil semuanya, dan jika lebih dari 100 maka diambil $10 \%-15 \%$ atau $20 \%-25 \%$ atau tergantung dari kebutuhan dan kemampuan peneliti. Karena populasinya berjumlah 150 maka kemudian diambil $20 \%$ dari 150 yakni 30, sehingga sampel yang digunakan adalah 30 orang siswa.

Metode pengumpulan data yang digunakan adalah metode angket sebagai metode pokok dan metode dokumentasi dan observasi sebagai metode pelengkap.Dalam penelitian ini, instrumen yang digunakan adalah berupa angket, bentuk angket yang digunakan dalam penelitian ini adalah bentuk angket tertutup. Adapun angket ini merupakan alat pengumpulan data yang dilakukan dengan cara memberi pertanyaan secara tertulis kepada responden untuk dijawab secara tertulis pula. Dalam penelitian ini, angket disusun dalam bentuk sejumlah pertanyaan untuk dijawab oleh responden (siswa) kaitannya dengan pengaruh bimbingan social terhadap kemandirian siswa SampelKelas VII SMPN 1Jonggat Lombok Tengah Dalam penelitian ini, variabel $\mathrm{x}$ disebut variabel bebas (indevendent variable) adalah bimbingan sosial dan variabel y disebut variabel terikat (devendent variable) adalah kemandirian.

\section{HASIL PENELITIAN}

Menyusun tabel deviasi pre-test dan post-test dimaksudkan untuk mengetahui deviasi yang diperoleh sebelum dan sesudah pemberian treatment bimbingan sosial siswa kelas VII SMPN 1 Jonggat Lombok Tengah yang berumlah 30 orang siswa, sehingga hasil yang diperoleh adalah cukup besar pengaruh treatment bimbingan sosial terhadap kemandirian siswasehingga perubahan yang terjadi dapat dilihat dari hasil nilai data angket pre test yaitu sebesar 1968 (dengan kode masing-masing siswa, $1 \mathrm{~S}=56, \mathrm{AR}=53$, $\mathrm{DH}=51, \mathrm{D}=56, \mathrm{H}=54, \mathrm{R}=55, \mathrm{RM}=49$, $\mathrm{RH}=60, \mathrm{LN}=63, \mathrm{AIS}=55, \mathrm{DS}=57, \mathrm{EAI}$ $=69, \mathrm{WDS}=65, \mathrm{AK}=57, \mathrm{EW}=41, \mathrm{KI}=49$, $\mathrm{MI}=54, \mathrm{WS}=54, \mathrm{RYS}=63, \mathrm{SA}=67, \mathrm{ML}=$ 59, $\mathrm{AA}=63, \mathrm{H}=63, \mathrm{TP}=62, \mathrm{DI}=62, \mathrm{SK}$ $=61, \mathrm{DY}=53, \mathrm{JR}=51, \mathrm{RM}$ dan $\mathrm{RS}=41$ ) dan nilai hasil post test yang diperoleh adalah sebesar 1878(dengan kode masing-masing, $\mathrm{IS}=60, \mathrm{AR}=63, \mathrm{DH}=64, \mathrm{D}=63, \mathrm{H}=58, \mathrm{R}$ $=60, \mathrm{RM}=50, \mathrm{RH}=67, \mathrm{LN}=68, \mathrm{AIS}=60$, $\mathrm{DS}=63, \mathrm{EAI}=76, \mathrm{WDS}=68, \mathrm{AK}=63, \mathrm{EW}$ $=52, \mathrm{KI}=56, \mathrm{MI}=64, \mathrm{WS}=60, \mathrm{RYS}=66$, $\mathrm{SA}=69, \mathrm{ML}=66, \mathrm{AA}=68, \mathrm{H}=73, \mathrm{TP}=65$, $\mathrm{D} 1=67, \mathrm{SK}=64, \mathrm{DY}=57, \mathrm{JR}=57, \mathrm{RM}=$ 59 dan $\mathrm{RS}=48$ ).

Dengan demikian dapat disimpulkan bahwa sebelum diberikan treatment(bimbingan sosial), hasil angket dari pre-testyaknikemandiriansangat rendah, berbeda dengan setelah mendapatkan perlakuan atau treatment bimbingan sosial dan melakukan pembagian angket post-test kembali kepada siswa dan hasilnya adalah terjadi perubahan $95 \%$, walaupun ada hasil data yang tidak sesuai dengan harapan peneliti, tetapi dari keseluruhan hasil yang 
telah di jumlahkan dan pemberian treatment yang dilakukan peneliti sangat berhasil.

Tabel kerja untuk menghitung nilai t dengan menggunakan rumus t-test

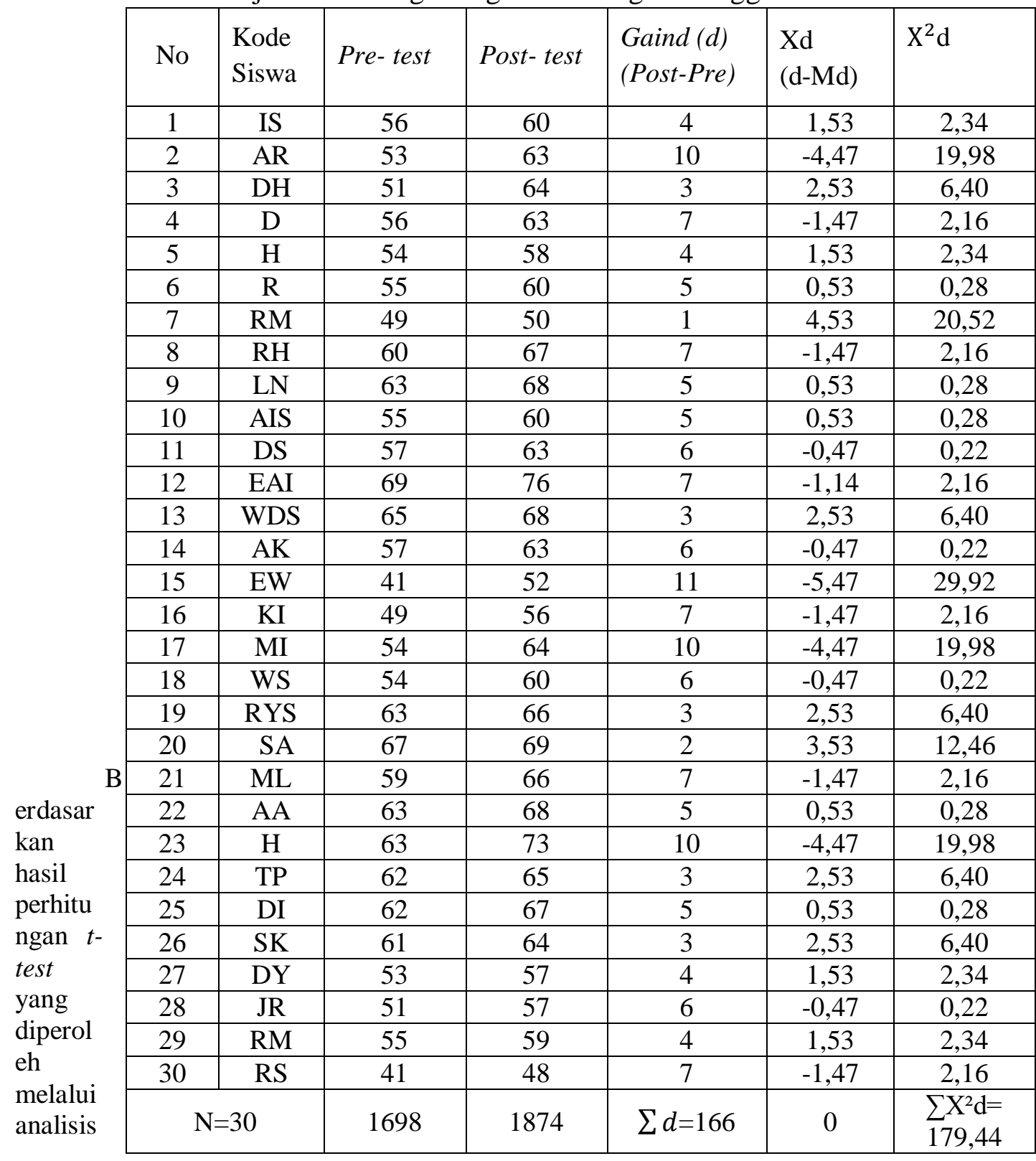

tabel, maka peneliti an ini dikatak an signifik an. Hal ini berarti bahwa hipotesi s nol di

ternyata nilai $\mathrm{t}$ diperoleh $=12,568$, kemudian dikonsultasikan dengan nilai $t$ dalam tabel dengan $\mathrm{db}(\mathrm{N}-1)=30-1=29$ dengan taraf signifikansi 5 $\%=2,045$. Berdasarkan hasil uji t-test menunjukkan nilai t hitung sebesar 12,568, maka berdasarkan taraf signifikan $5 \%$ dan db $(\mathrm{N}-1)=$ 29 ternyata besarnya angka batas penolakan hipotesis nol yang dinyatakan dalam tabel distribusi t adalah 2,045.

Kenyataan ini menunjukkan bahwa nilai $t$ hitung lebih besar dari pada nilai t tabel (12,568 > 2,045), karena $\mathrm{t}$ hitung lebih besar dari nilai $\mathrm{t}$ tolak dan hipotesis alternatif diterima, maka dapat ditarik kesimpulan bahwa : Ada Pengaruh bimbingan sosial terhadap kemandirian siswa kelas VII SMPN 1 Jonggat Lombok Tengah.

\section{PEMBAHASAN}

Penelitian ini, analisis data dilakukan dua kali yaitu sebelum dan sesudah diberikan treatment perlakuan bimbingan sosial.Karena dalam penelitian ini menggunakan one group pretest post-test design.Dengan demikian, bahwa pelaksanaan bimbingan sosial mempunyai 
peranan yang positif dalam membantu siswa dalam peningkatan kemandirian pada siswa kelas VII SMPN 1 jonggat Lombok Tengah. Kemandirian biasanya ditandai dengan kemampuan menentukan nasib diri sendiri, kreatif dan inisiatif, mengatur tingkah laku, bertanggung jawab, mampu menahan diri, dan membuat keputusan-keputusan sendiri, serta mampu mengatasi masalah tanpa ada pengaruh dari orang lain. Kemandirian juga berarti usaha untuk melepaskan diri dari orang tua dengan maksud untuk menemukan dirinya melalui proses mencari identitas ego, yaitu merupakan perkembangan kearah individualitas yang mantap dan berdiri sendiri.

Lebih jauh lagi, pelaksanaan bimbingan sosial sangat berguna bagi peningkatan kemampuan siswa untuk membentuk menjadi pribadi yang mandiri karena siswa lebih paham tentang hal-hal yang memang seharusnya dilakukan secara mandiri, tetapi karena lingkungan yang selalu bersifat sudah menyediakan, jadi seorang anak terkadang kurang mau untuk berusaha sendiri. Dengan pelaksanaan bimbingan sosial guru membantu siswa ini berfungsi untuk membantu siswa dalam membentuk kemandiriannya, sehingga dapat berkembang secara optimal, mengenal dan berhubungan dengan lingkungan sosial yang dilandasi budi pekerti luhur, tanggung jawab, kemasyarakatan dan kenegaraan.

Dengan Bimbingan sosial pula guru dapat membantu siswa dalam meningkatkan pemahaman diri dan perubahan sikap serta kebutuhannya terpenuhi, maka siswa akan mampu berdiri sendiri dan akan muncul dengan pribadi yang mandiri, baik mandiri dalam sikap,tingkah laku, maupun pengambilan keputusan dalam setiap masalah yang dihadapinya, inisiatif untuk mengatasi masalah, memiliki kepercayan diri serta mampu bertanggung jawab atas apa yang telah dilakukannya.

Dengan demikian, bahwa pelaksanaan bimbingan sosial mempunyai peranan yang positif dalam membentuk kemandirian pada siswa kelas VII SMPN 1 Jonggat Lombok Tengah, dengan kata lain semakin intensif pelaksanaan bimbingan sosial di sekolah, maka semakin meningkat kemandirian pada siswa.
Berdasarkan hasil analisis data maka dapat disimpulkan bahwa : ada pengaruhbimbingansosialterhadapkemandirianpa dasiswakelas VII SMPN 1 Jonggat Lombok Tengah. Hal ini dapat dilihat dari hasil penelitian yaitu : nilai t hitung sebesar 12,568 dan nilai t tabel pada tarap signifikan 5\% dengan tabel dengan db $(\mathrm{N}-1)=30-1=29$, dengan nilai lebih besar dari pada nilai t pada tabel $(12,568>2,045)$. Sehingga dapat disimpulkan " signifikan".

\section{DAFTAR PUSTAKA \\ Ali \&Asrori. 2010. Psikologi Remaja (Perkembangan Peserta Didik). Jakarta: PT. Bumi Aksara. \\ Arikunto, Suharsimi. 2002. Metode Penelitian Suatu Pendekatan Praktek.Jakarta: Rineka Cipta.}

Desmita. 2009. Psikologi Perkembangan Peserta Didik. Bandung: PT Remaja Rosda karya.

Fatimah, E. 2010.Psikologi Perkembangan Pesertadidik. Bandung: CV Pustaka Setia.

Hasan Basri. 2000. Remaja Berkualitas Problematika Remaja dan Solusinya. Yogyakarta: Pustaka Pelajar.

Steven R. Covey. 1997.The Seven Habits of Highly Effective People, terjemahan Budijanto. Jakarta: Binarupa Aksara.

Sukardi. 2004. Pengantar Pelaksanaan Program BK di Sekolah. Jakarta: PT. Rineka Cipta.

Sumahamijaya Suparman, dkk. 2003. Pendidikan Karakter Mandiri Dan Kewirausahaan. Bandung:Angkasa.

Sugiyono. 2011. Metode Penelitian Pendidikan (Pendekatan Kuantitatif, Kualitatif, dan R\&D). Bandung: Alfabeta.

Tohirin. 2013. Bimbingan dan Konseling di Sekolah dan Madrasah (Berbasisintegrasi). Jakarta: Raja Grafindo Persada.

Parker.2006.Developing Children Indepedency and Estemm, Diterjemahkan oleh Bambang Wibisono, Jakarta:Prestasi Pustaka.

Yuliani Nurani Sujiona. 2007. Buku Ajar Konsep Dasar Pendidikan Anak Usia Dini. Jakarta:UNJ.

Yamin Martinis, Sanan Jamilah Sabri. 2013. Panduan Paud (Pendidikan Anak Usia 
Jurnal Visionary (VIS) 